\title{
Chemical analysis of Ricinus communis L. (Euphorbiaceace) seed kernel extract and its in-vitro toxicity in two Podagrica Species (Coleoptera: Chrysomelidae)
}

\author{
Adeleke G.E ${ }^{1}$., Ehigie L.O ${ }^{1}$., Olayioye $\mathrm{A}^{2}$., Oyegoke O.O ${ }^{3}$., Adedosu O.T ${ }^{1^{*}}$., Raheem O.K ${ }^{1}$., Ugbor C.M ${ }^{1}$ \\ 1. Department of Biochemistry, Faculty of Basic Medical Sciences, Ladoke Akintola University of \\ Technology, Ogbomoso, Oyo State, Nigeria.
}

2. Department of Crop and Environmental Protection, Faculty of Agriculture, Ladoke Akintola University of Technology, Ogbomoso, Oyo State, Nigeria.

3. Department of Pure and Applied Biology (Entomology Unit), Ladoke Akintola University of Technology, Ogbomoso, Oyo State, Nigeria.

"Corresponding Author: Adedosu O.T. (otadedosu@lautech.edu.ng)

\begin{abstract}
Since synthetic pesticides are associated with many toxicological problems against untargeted subjects, pesticides from botanical sources become a better option. This study obtained $R$. communis seed kernel extract (RCSKE) through acidified aqueous extraction. The extract was screened using Infra red (IR) and Ultraviolet (UV) spectroscopy, High-Performance Liquid Chromatography (HPLC) and Cass Chromatography (GC) for bioactive agents. In-vitro effects of RCSKE, chlorpyrifos (CPF) and cypermethrin (CYPER-M) on superoxide dismutase (SOD), Catalase (CAT), acetylcholinesterase (AChE) and Carboxylesterase (CE) activities in Podagrica sjosdteti and Podagrica uniforma were determined spectrophotometrically. The IR and UV of RCSKE majorly depict the presence of aromatic ring, ethylenic bond, carbonyl bond, hydroxyl and carboxylic groups. The HPLC and GC majorly show the presence of ricinoleic acid, ricinine and ricin. The RCSKE, CYPER-M and CPF increased CAT activity in P. sjosdteti, but reduced it in P. uniforma. The RCSKE and CYPER-M significantly reduced SOD, and elevated AChE activities in P. sjosdteti. The $\mathrm{IC}_{50}$ values of RCSKE, CYPER-M and CPF against CE activity in $P$. sjosdtet $i$ were $\mathrm{IC}_{50}=2.66 \mu \mathrm{g} / \mathrm{ml}, \mathrm{IC}_{50}=2.37 \mu \mathrm{g} / \mathrm{ml}$ and $\mathrm{IC}_{50}=2.65$ $\mu \mathrm{g} / \mathrm{ml}$ ), respectively, while that of RCSKE against $P$. uniforma was $\mathrm{IC}_{50}=2.49 \mu \mathrm{g} / \mathrm{ml}$. This study suggests that the extract of Ricinus communis seed kernel contains bioactive substances, capable to inhibit the antioxidant, acetylcholinesterase and carboxylesterase enzymes in Podagrica species flea beetles, comparable to commercial pesticides, Cypermethrin and Chlorpyrifos.
\end{abstract}

Key words: Ricinus communis, Chemical screening, Podagrica sjosdteti, Podagrica uniforma, antioxidant enzymes, hydrolytic enzymes

DOI: $10.7176 /$ ALST/75-05

Publication date:June $30^{\text {th }} 2019$

\section{Introduction}

Ricinus communis L. (Castor) plant has been reported to originate from India, the southeastern Mediterranean Basin, and Africa, and has even become widely distributed throughout the tropics and even beyond (Sabina, 2009). In the tropics, the plant grows as a perennial plant with heights between 10 and $12 \mathrm{~m}$, while in the temperate regions, it is an annual plant with heights between 1-3 m, as documented by Salihu et al. (2013).

A recent study has shown that Castor beans contain about 40 to $60 \%$ oil, which is highly rich in triglycerides, predominantly ricinolein (Azizat et al., 2016). Castor oil has been demonstrated to contain a mixture of saturated and unsaturated fatty acids, such as, ricinoleic acid, linoleic acid, stearic acid, palmitic acid, linolenic acid, ecosanoic acid and dihydroxystearic acid (Aplin and Eliseo, 1997; Gana et al., 2013). The oil is among the most sought-after oils of plant origin, mainly due to its various properties and applications, and has therefore gained world-wide increase in production, as established by NCRI (2014). Castor oil (CB) is widely used for several medicinal purposes and for making products like cosmetics, paints, lubricants and many others as reported by Ogunniyi (2006) and Worbs et al. (2011). However, certain clinical manifestations following CB toxicity have been reported such as oropharyngeal irritation, abdominal pain, vomiting and diarrhea bleeding 
(Coopmann et al., 2009), and hypoglycemia and hemolysis (Balali-Mood and Moshri, 2015). Several studies have documented the presence of phytochemicals such as, alkaloids (Trease and Evans. 1989), cardiac glycosides, tannins and flavonoids (Edeoga et al., 2005), steroids, saponins and anthraquinones (Aziz et al., 2016) in castor bean oil. Castor seed kernel has been shown to contain a toxic glycoprotein, known as ricin (Azziz et al., 2016), which is a heterodimeric toxin, capable of ribosome-inactivation and fatal disruption of protein synthesis in mammalian species (Audi et al., 2005). This toxic glycoprotein enters animal cells via several processes, and the presence of a single ricin molecule in the cytosol could potentially kill the entire cell (Berman et al., 2011). In addition to ricin, castor also contains some other toxic agents such as ricinine (alkaloid) and castor bean allergen (CBA), which together with ricin, are not usually extracted in the oil (ICOA, 2013). Berman et al, (2011) have suggested that certain monoterpenoids and sesquiterpenoids present in castor leaves exhibit cytotoxicity against cancer cells, by inducing apoptosis via translocation of phosphatidyl serine to the external surface of the cancer cell membrane. This results in perturbation of mitochondrial membrane potential and eventual cell death. An investigation by Salihu et al. (2013) has demonstrated the potential of castor against the damaging activity of termites on Mangifera indica and Pinus longifolia, reporting significant weight loss in the woods. Furthermore, it has been reported that the various active substances in castor could potentially interfere with the life cycles of many insect pests, including Callosobruchus chinensis (Uspani et al., 2003), Cosmopolites sordidus (Tinzarra et al., 2006), Spodoptera frugiperda (Rossi et al., 2012) and Musca domestica (housefly) Singh and Kaur (2016).

The adult flea beetles are usually small in size ranging from 1.5 to $3.0 \mathrm{~mm}$ long. They damage the cotyledon and foliar leaves of crops (Lamb, 1984). Several genera of flea beetles, including Diamphidia spp. (Nuewinger, 1996), Procalus spp. (Jerez, 1999), Blepharida spp. (Furth and Lee, 2000), Ophridia spp. and Asiophridia spp. (Zhang and Yang, 2008), Polycladia spp. (Chaboo, 2011) and Podagrica spp. (Ojo et al., 2014), have been documented to be distributed in different localities, all over the world. In West Africa, the economic damage through defoliation of crops, such okra, by two species of flea beetles, Podagrica uniforma (Jac.) and Podagrica sjostedti (Jac.) (Coleoptera: Chrysomelidae) have been reported. The former has shiny brown elytra, while the latter has bluish-black elytra Odebiyi (1980), and Osisanya and Tayo (1981). A study carried out by Abebe (2015) has noted that a spray of foliar insecticides like sevin and endosulfan was effective against Podagrica puncticolis, resulting in increase in crop yield. In addition, the use of insecticides extracted from plants, such as neem, pawpaw and onion bulbs, have proved effective against Podagrica sjosdteti and Podagrica uniforma hosted by okra plant, as investigated by Ojo et al. (2014). The two species infest okra plants from germination up to the stage of fruition. They cause destruction of both the foliage and matured leaves, with loss of photosynthetic capacity (Fasunwon ant Banjo, 2010), as well as transmission of mosaic virus, which leads to 20-50\% reduction in crop yield (Fajinmi and Fajinmi, 2010). We discovered that literature information on the toxicity of $R$. communis (castor) against the two local species of flea beetles, Podagrica sjosdteti and Podagrica uniforma, was actually scarce. The present study was therefore designed to chemically determine the bioactive agents in $R$. communis seed kernel extract (RCSKE) and evaluate the in-vitro effects on selected antioxidant and hydrolytic enzymes of the two species of Podagrica flea beetles.

\section{Materials and Methods}

\section{Chemicals}

Dithionitrobenzoic acid, Ethylenediamine tetraacetic acid (EDTA), para-nitrophenylacetate, para-nitrophenol, Triton-X-100, acetylthiocholine iodide, Adrenaline and Commercial pesticides (cypermethrin and chlorpyrifos). All other reagents were of good analytical grades.

\section{Acidified aqueous extraction of Castor seed kernel}

Fresh Fruits of Castor plant (Ricinus Communis) were collected from Lagbedu-Orile near Ogbomoso, Oyo state, Nigeria in March, 2018. The fruits were air-dried at room temperature for 3 weeks, depulped and then pulverized $(261.95 \mathrm{~g})$ using mortar and pestle to obtain an oily pasty substance. The oily pasty substance was defatted using $1000 \mathrm{ml}$ of n-Hexane at room temperature for 48 hours, followed by filtration through a linen cloth. The residue (Residue A), which was expected to contain Ricin, Ricinine and Ricinoleic acid, was subjected to acidified aqueous extraction described by Walker and Negis, (1958) with modifications. Briefly, the residue A was redissolved in $500 \mathrm{ml}$ of distilled water in $1000 \mathrm{ml}$ beaker and then acidified with concentrated $\mathrm{HCl}$ to obtain a mixture at $\mathrm{pH}$ 3.8. The resulting mixture was subjected to batch stirring for 24hours using a Magnetic Stirrer. The mixture was allowed to settle for 24 hours at the room temperature, and then filtered through a linen cloth to obtain a filtrate (Filtrate A), and the residue (Residue B) was re-dissolved in $250 \mathrm{ml}$ distil water in a $1000 \mathrm{ml}$ beaker and re-stirred for 2 hours, filtered to obtain filtrate B. Both filtrates A and B were pooled and allowed to settle for 24 hours, to allow the filtrate separate into two layers (a fluffy white upper layer and a lower clear colorless layer). The fluffy layer was removed by using a Pasteur's pipette into a beaker and labeled residue C. 
The clear colorless liquid layer was precipitated by saturation with $5.69 \mathrm{M}$ solution of Sodium chloride, and then centrifuged at $3000 \mathrm{x}$ g for 5 minutes. The topmost fluffy white layer was collected using a Pasteur's pipette and labeled as Residue D. The resulting liquid layer was further subjected to saturation with $2.35 \mathrm{M}$ solution of $\mathrm{Na}_{2} \mathrm{SO}_{4}$ and then centrifuged at $3000 \mathrm{x}$ g for 5 minutes. The topmost fluffy white layer was collected and labeled Residue E. The Residues C, D, and E were pooled (pH adjusted to 8.0) and evaporated using a rotary evaporator and concentrated in an oven at $40-45^{\circ} \mathrm{c}$ (Singh and Kaur, 2016) to obtain dry Ricinus communis seed kernel extract (RCSKE). The dry extract was kept in an air-tight bottle at $4{ }^{\circ} \mathrm{c}$ until use.

\section{Ultraviolet (UV) and Infrared (IR) spectroscopic analyses}

The UV -1800 series machine was used to analyze the light brown solid Ricinus communis seed kernel extract (RCSKE) at a wavelength of 340nm to obtain visible spectra. The IR spectral analysis of the Ricinus communis seed kernel extract (RCSKE) was done using an Agilent machine (USA), expressing the wavelength in reciprocal centimeter $\left(\mathrm{cm}^{-1}\right)$.

\section{High-Performance Liquid Chromatographic (HPLC) analysis}

An isocratic HPLC (Mumbai machine) profiling was carried out on the Ricinus communis seed kernel extract (RCSKE) at a flow rate of $0.5 \mathrm{~mL} / \mathrm{min}$. Exactly $25 \mathrm{mg}$ of the extract was dissolved in the mobile phase containing a mixture of acetonitrile and methanol $(80: 20, \mathrm{v} / \mathrm{v})$, and the injection volume was $20 \mu \mathrm{L}$. The $\mathrm{C}_{18}(4.5$ $\mathrm{x} 250 \mathrm{~mm}, 5 \mu \mathrm{m}$ ) column was maintained at the room temperature and the eluent was detected at $210 \mathrm{~nm}$ with a run time of 30 minutes.

\section{Gas Chromatographic (GC) analysis}

The extract was subjected to a Gas Chromatography-Flame Ionization Detector (GC-FID) machine (HP Series II- 5890). The carrier gas was Nitrogen at a flow rate of $22 \mathrm{ml} / \mathrm{min}$ and the air flow rate was $45 \mathrm{ml} / \mathrm{min}$. The initial temperature was $50^{\circ} \mathrm{c}$. Using the peak areas from the chromatogram, the percentage composition of each constituent was calculated.

\section{Collection and homogenization of insects}

Fifty each of Podagrica sjosdteti and Podagrica uniforma were collected using a sweeping net on an okra plantation located at Obamoro village, Osun State, Nigeria. They were confirmed by Dr. Olayioye A. (Department of Crop and Environmental Protection, Faculty of Agricultural Science) and Professor Oyegoke O.O. (Entomology Unit, Department of Pure and Applied Biology), Ladoke Akintola University of Technology, Ogbomoso, Oyo State, Nigeria. Each of the two insect groups was divided into two portions (twenty-five insects each) and then de-winged. One portion each of the insect species was homogenized using phosphate buffer ( $\mathrm{pH}$ 7.4) and centrifuged at $10000 \mathrm{x}$ g for 10 minutes. The supernatant was kept at $4^{0} \mathrm{c}$ until use. The second portion was processed for Carboxylesterase activity determination as described later in this work.

\section{Biochemical Assays}

\section{Protein determination}

The protein levels of the insect homogenates were determined according to the method of Lowry et al. (1951) using bovine serum albumin as standard.

\section{Determination of Superoxide dismutase activity}

Activities of superoxide dismutase (SOD) in insect homogenates were determined by the method of Misra and Fridovich (1975). Briefly, an aliquot of $0.2 \mathrm{ml}$ of the diluted insect homogenate was added to $2.5 \mathrm{ml}$ of $0.05 \mathrm{M}$ carbonate buffer ( $\mathrm{pH} 10.2)$ to equilibrate in the spectrophotometer. Then, $0.2 \mathrm{ml}$ of RCSKE $(15,30,45,60,75$, 90 and $105 \mu \mathrm{g} / \mathrm{ml}$ ) followed by $0.3 \mathrm{ml}$ of freshly prepared $0.3 \mathrm{M}$ adrenaline (substrate) were added to the mixture. Similar concentrations of commercial Cypermethrin (Pyrethroid) and Chlorpyrifos (Organophosphate) were separately used as standards (positive controls) in place of the extract. The negative control was without RCSKE or the commercial pesticides. The absorbance was taken spectrophotometrically at 480nm every 30 seconds for 150 seconds, and enzyme activity was expressed as Units/mg protein.

\section{Determination of Catalase activity}

Catalase activities in the insect homogenates were determined by described by Aebi (1984). The assay is based on the ability of the enzyme to promote decomposition of hydrogen peroxide. The assay mixture contained $4 \mathrm{ml}$ of hydrogen peroxide solution $(0.2 \mathrm{M})$ and $5 \mathrm{ml}$ of Phosphate buffer $(0.01 \mathrm{M}, \mathrm{pH} 7.0)$ in a $10 \mathrm{ml}$ flat bottom flask. A $1.0 \mathrm{ml}$ of properly diluted enzyme preparation (insect homogenate) was rapidly mixed with the reaction 
mixture by a gentle swirling motion and $0.3 \mathrm{ml}$ of $\operatorname{RCSKE}(15,30,45,60,75,90$ and 105 $\mu \mathrm{g} / \mathrm{ml})$ was added in separate test tubes at the room temperature. Similar varying concentrations of commercial Cypermethrin and Chlorpyrifos were separately used as standards (positive controls) in place of the extract. The negative control was without RCSKE or the commercial pesticides. A $1 \mathrm{ml}$ portion of the reaction mixture was blown into $2 \mathrm{ml}$ of dichromate acetic acid reagent at 60 seconds intervals Change in absorbance was monitored at 240nm for 180 seconds at an interval of 60 seconds, and the enzyme activity was expressed as units/mg protein.

\section{Acetylcholinesterase Activity}

Acetylcholinesterase (AChE) activities in insect homogenates were determined according to the methods described by Ellman, (1961), and Nachmansohn and Neumann, (1975) with modification. The reaction mixture contained $2.6 \mathrm{ml}$ phosphate buffer $(0.1 \mathrm{M}, \mathrm{pH} 7.4), 0.1 \mathrm{ml}$ Ellman's reagent (DTNB), $0.4 \mathrm{ml}$ insect homogenate and $0.3 \mathrm{ml} \operatorname{RCSKE}(15,30,45,60,75,90$ and $105 \mu \mathrm{g} / \mathrm{ml})$. Then $0.1 \mathrm{ml}$ of Acetylthiocholine iodide solution was added to the reaction mixture, as substrate to trigger the reaction. Similar varying concentrations of commercial Cypermethrin and Chlorpyrifos were separately used as standards (positive controls) in place of the extract. The negative control was without RCSKE or the commercial pesticides. The rate of acetylcholinesterase activity was measured spectrophotometrically by following the increase in intensity of the yellow product at $412 \mathrm{~nm}$ for 10 mins at an interval of 2 mins.. Acetylcholinesterase activity was calculated using the formula below with the molar extinction of $1.361 \mathrm{x} \mathrm{mmol}^{-1} \mathrm{xmm}^{-1}$ :

\section{AChE activity $=\quad$ Change in absorbance $\mathrm{x}$ Total reaction volume Time $\mathrm{x}$ sample volume $\mathrm{x}$ molar extinction}

$\mathrm{AChE}$ activity $=\mathrm{U} / \mathrm{mg}$ protein

\section{Carboxylesterase Activity}

Carboxylesterase (CE) activities in insect homogenates were determined using the method described by Clement and Erhardt (1990), with modifications, using paranitrophenyl acetate as a substrate for the enzyme. Insects were homogenized in ice-cold Tris- $\mathrm{HCl}$ buffer $\left(0.1 \mathrm{M}, \mathrm{pH} 7.8\right.$ with $1 \%$ Triton $\mathrm{X}-100$ at $\left.25^{\circ} \mathrm{C}\right)$ using a tissue homogenizer. The homogenate was centrifuged in a refrigerated centrifuge at $10,000 \mathrm{x} \mathrm{g}$ for $10 \mathrm{mins}$ at $4{ }^{0} \mathrm{C}$. The supernatant was diluted with distilled water in ratio $1: 10$. An aliquot of $0.5 \mathrm{ml}$ of diluted supernatant (crude enzyme preparation) was added to $2 \mathrm{ml}$ of the working buffer $(0.1 \mathrm{M}$ Tris- $\mathrm{HCl}$, pH 7.8 , containing $2 \mathrm{mM}$ EDTA at $25{ }^{\circ} \mathrm{C}$ ) followed by $0.3 \mathrm{ml}$ of $\operatorname{RCSKE}(15,30,45,60,75,90$ and $105 \mu \mathrm{g} / \mathrm{ml})$. The mixture was incubated at 37 ${ }^{0} \mathrm{C}$ for 10 minutes and the reaction was started by adding $0.2 \mathrm{ml}$ of $50 \mathrm{mM}$ paranitrophenyl acetate (prepared in acetone) as a substrate. Similar varying concentrations of commercial Cypermethrin and Chlorpyrifos were separately used as standards (positive controls) in place of the extract. The negative control was without the extract or commercial pesticides. The change in absorbance was read spectrophotometrically at $405 \mathrm{~nm}$, at an interval of $1 \mathrm{~min}$ for 5 minutes at $405 \mathrm{~nm}$. The blank reagent contained $2 \mathrm{ml}$ working buffer and $0.2 \mathrm{ml}$ paranitrophenyl acetate. A paranitrophenol standard curve was prepared to calculate Carboxylesterase activity, expressed as $\mathrm{nmol} / \mathrm{min} / \mathrm{ml}$ protein.

\section{Statistical Analysis}

All values (in duplicates) were expressed as the mean \pm standard deviation. One-way analysis of variance (ANOVA) was done to determine differences in treatments, while probit analysis (Annie et al., 2015) was done to evaluate the half maximal inhibitory concentration $\left(\mathrm{IC}_{50}\right)$ using SPSS software. Statistically significant values were taken at $\mathrm{p}<0.05$.

\section{Results}

\section{Spectroscopy and Chromatography}

The Infra red (IR) spectrum of $R$. communis seed kernel extract (RCSKE) showed ten notable peaks at 1082.8 $\mathrm{cm}^{-1}, 1161.1 \mathrm{~cm}^{-1}, 1239.3 \mathrm{~cm}^{-1}, 1459.7 \mathrm{~cm}^{-1}, 1541.3 \mathrm{~cm}^{-1}, 1654.9 \mathrm{~cm}^{-1}, 2855.1 \mathrm{~cm}^{-1} 2926.0 \mathrm{~cm}^{-1}, 3013.6 \mathrm{~cm}^{-1}$ and $3289.4 \mathrm{~cm}^{-1}$, as shown in Figure 1. The Ultra violet (UV) spectroscopy of the extract was found to depict absorptions at four different wavelengths at $222.5 \mathrm{~nm}, 228.5 \mathrm{~nm}, 258.5 \mathrm{~nm}$ and $275.5 \mathrm{~nm}$ (Figure 2). The HPLC spectrum of RCSKE (Figure 3) shows six prominent peaks with retention times of $1.309 \mathrm{~min}, 1.476 \mathrm{~min}, 1.804$ min, $2.593 \mathrm{~min}, 3.252 \mathrm{~min}$ and $5.446 \mathrm{~min}$. The GC chromatogram in figure 4 shows that the analysis of RCSKE exhibited nine different peaks (and their retention times), which include Ethyl ester (4.223min), Diethyl phthalate (4.783min), 1,4a-Lactone (5.000min), GIBB- 3-ENE-1 (5.2666min), Oleic acid (5.500min), Ricinoleic acid (7.783 min), Ricinine (9.666 min), Ricin (10.283min) and Octadecanoate (10.816min). Their respective peak areas (and \% compositions) include 1394.5285mAU*S (6.27\%), 423.9710mAU*S (1.91\%), 361.1000mAU*S 
(1.62\%), 784.2020mAU*S (3.52\%), 6081.5680mAU*S (27.33\%), 1543.9470mAU*S (6.94\%), 6743.4680 mAU*S (30.31\%), 3710.8845mAU*S (16.68\%) and 1206.9510mAU*S (5.42\%).

\section{Antioxidant enzymes}

Table 1 has shown that at all the concentrations $(15-105 \mu \mathrm{g} / \mathrm{ml})$ used in this study, in vitro catalase (CAT) activity was significantly $(\mathrm{p}<0.05)$ increased by the RCSKE, Cypermethrin and Chlorpyrifos in Podagrica sjosdteti. However, the CAT activity was observed to be significantly reduced by these same agents in Podagrica uniforma compared to control. The result shown in table 2 depicts that at all the concentrations used in the study, the activity of superoxide dismutase (SOD) was significantly $(\mathrm{p}<0.05)$ reduced by the RCSKE, Cypermethrin and Chlorpyrifos in P. sjosdteti. On the other hands, in $P$. uniforma, SOD activity was found to be significantly lowered by only RCSKE and Cypermethrin, while Chlorpyrifos effect was insignificant ( $\mathrm{p}>0.05)$.

\section{Esterase enzymes}

The present study also examined the effects of the extract, CYPER-M and CPF on the activities of Acetylcholinesterase (AChE) and Carboxylesterase (CE) in the two species of Podagrica, and the results are presented in figures 5, 6, 7 and 8. The result in figure 5 shows that RCSKE and CYPER-M significantly elevated ( $\mathrm{p}<0.05)$ AChE activity in $P$. sjosdteti at nearly all the concentrations $(15-105 \mu \mathrm{g} / \mathrm{ml})$ used compared with control. On the other hands, CPF was found to significantly reduce the AChE activity at all the concentrations in the same insect species relative to control. Figure 6 has shown that the in vitro AChE activity in P. uniforma was significantly increased $(\mathrm{p}<0.05)$ at all the concentrations used for the study compared with the control. The result in figure 7 has revealed that RCSKE, CYPER-M and Chlorpyrifos significantly reduced $(\mathrm{p}<0.05)$ the in vitro activity of Carboxylesterase enzyme in P. sjosdteti at all the concentrations used compared with control. Lastly, in figure 8, the activity of Carboxylesterase in $P$. uniforma was observed to be significantly reduced ( $\mathrm{p}<$ 0.05) by treatment with the extract (RCSKE) at all the concentrations. However, on treatment with CYPER-M and CPF, the activity of the CE enzyme was slightly elevated compared with control. The result of The probit analysis (Table 3) shows the individual potency of RCSKE, Cypermethrin and Chlorpyrifos on Carboxylesterase (CE) activity in the two Podagrica species. The $\mathrm{IC}_{50}$ values of the three agents were found to be $2.66 \mu \mathrm{g} / \mathrm{ml}, 2.37 \mu \mathrm{g} / \mathrm{ml}$ and $2.65 \mu \mathrm{g} / \mathrm{ml}$, respectively, for $P$. sjosdteti. However, for $P$. uniforma, the $\mathrm{IC}_{50}$ value of RCSKE was determined to be $2.49 \mu \mathrm{g} / \mathrm{ml}$, while similar values for CYPER-M and CPF could not be determined. 


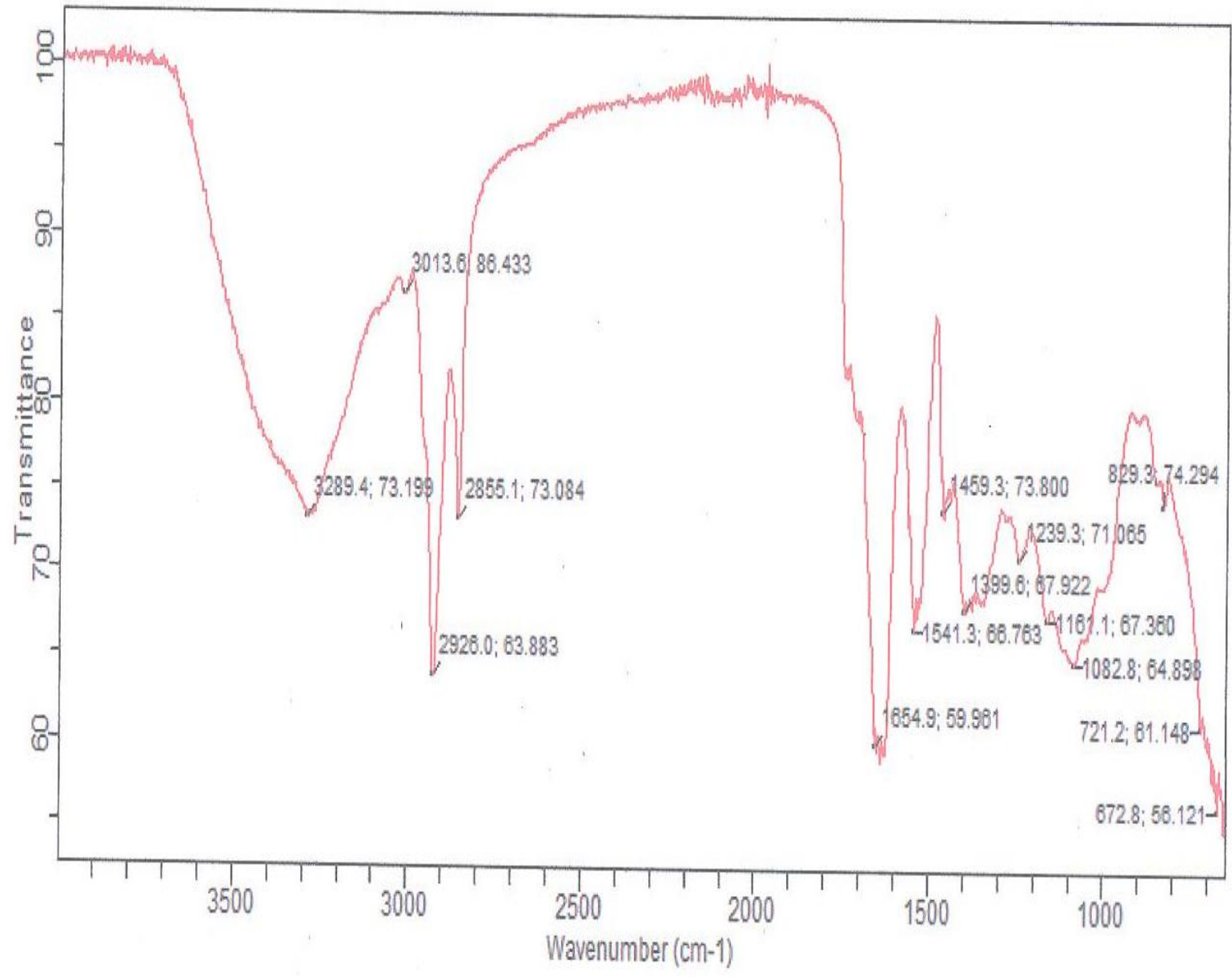

Figure 1. Infra red (IR) spectrum of Ricinus communis seed kernel extract (RCSKE) 


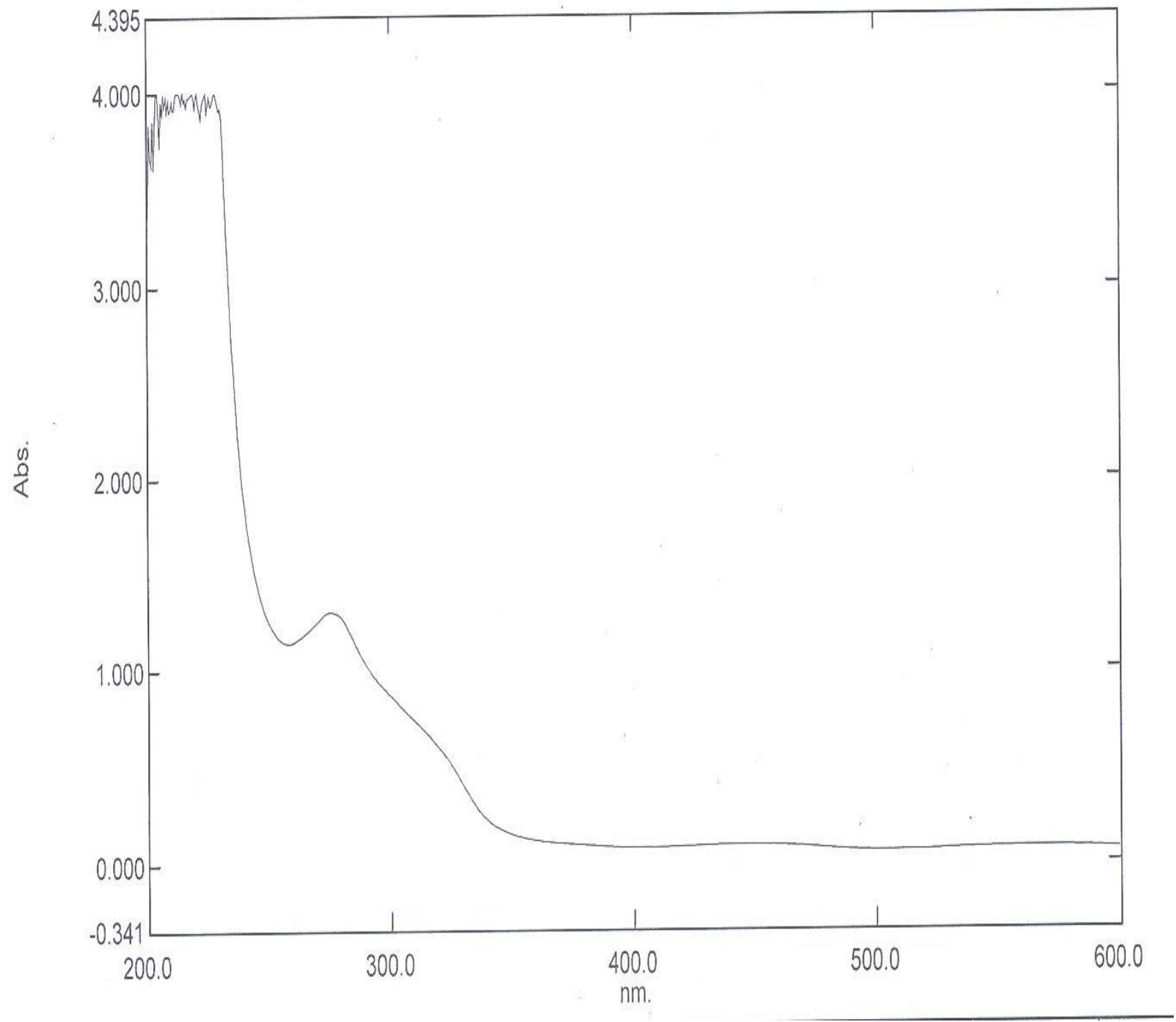

Figure 2. Ultra violet (UV) spectrum of Ricinus communis seed kernel extract (RCSKE) 


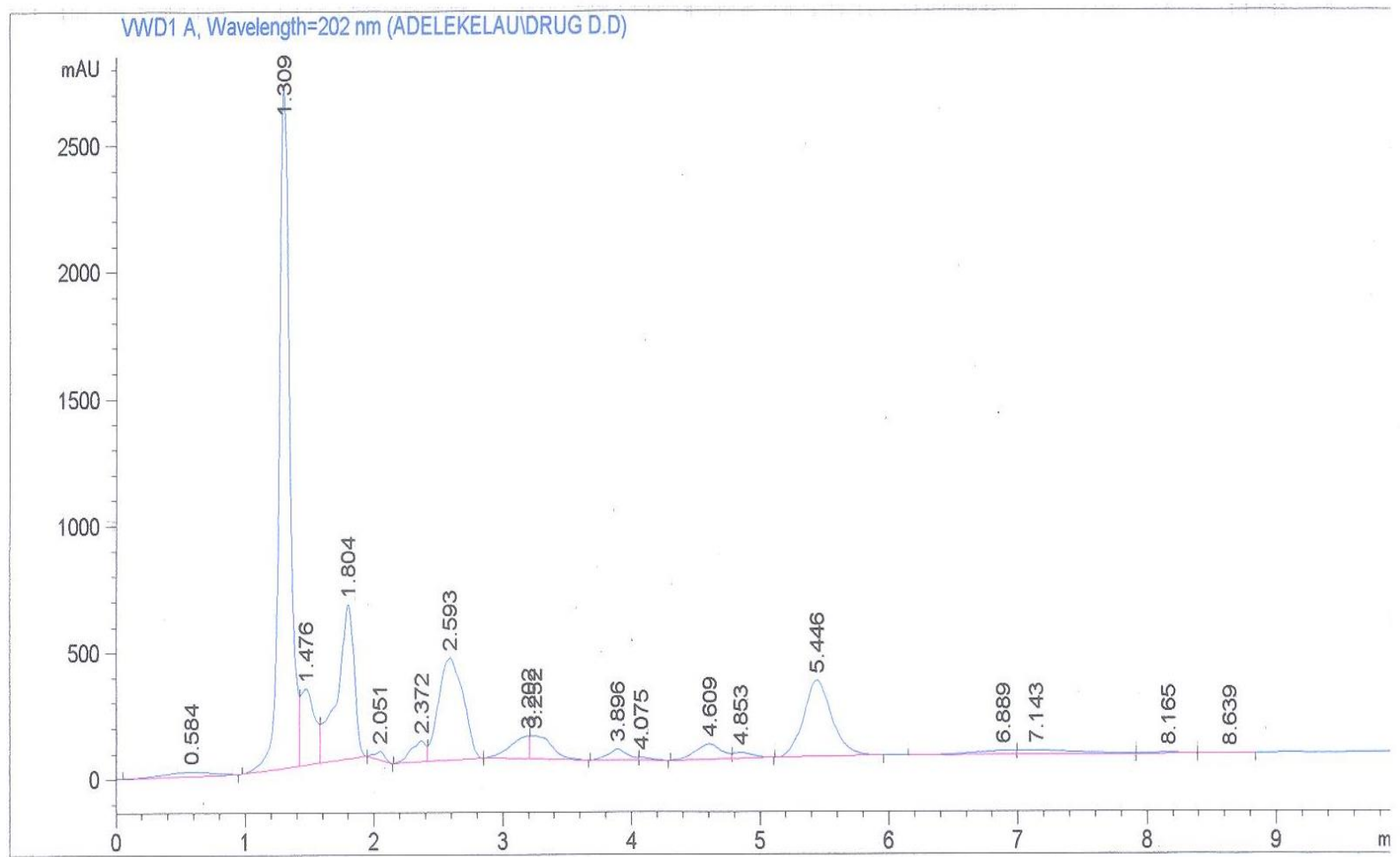

Figure 3. High Performance Liquid Chromatographic Chromatogram of Ricinus communis seed kernel extract (RCSKE) 


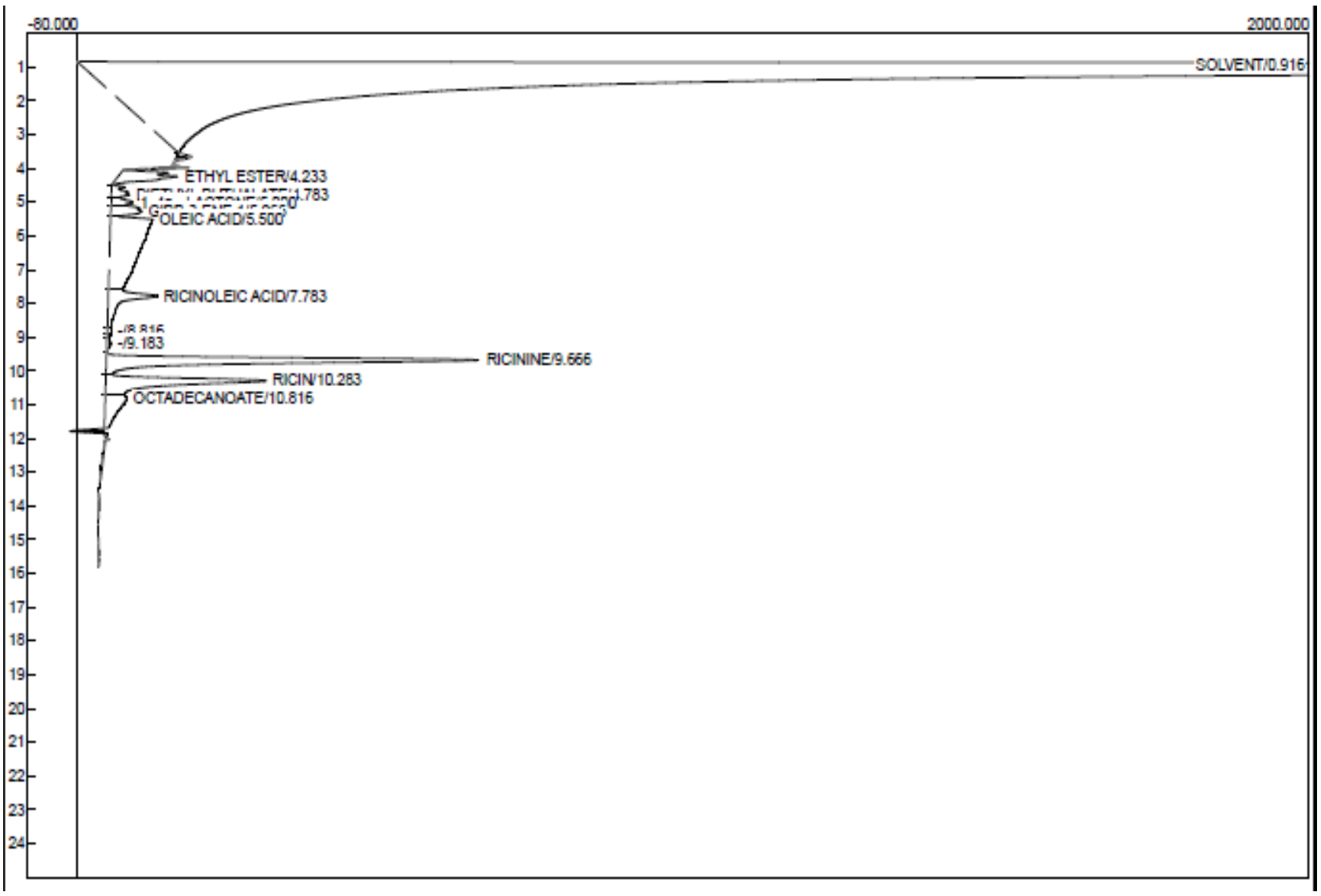

Fig. 4. Gas Chromatographic Chromatogram of Ricinus communis seed kernel extract (RCSKE) 
Table 1. Effects of RCSKE, Cypermethrin and Chlorpyrifos on catalase activity in Podagrica sjosdteti and

\begin{tabular}{|l|l|l|l|l|l|l|}
\hline \multirow{2}{*}{$\begin{array}{l}\text { Conc. } \\
(\mu \mathrm{g} / \mathrm{ml})\end{array}$} & \multicolumn{3}{|l|}{$\begin{array}{l}\text { Catalase activity (U/mg protein) in Podagrica } \\
\text { sjosdteti }\end{array}$} & $\begin{array}{l}\text { Catalase activity (U/mg protein) in Podagrica } \\
\text { uniforma }\end{array}$ \\
\cline { 2 - 7 } & CRSKE & Cypermethrin & Chlorpyrifos & CRSKE & Cypermethrin & Chlorpyrifos \\
\hline 15 & $2.48 \pm 0.10^{\mathrm{a}}$ & $1.42 \pm 0.02^{\mathrm{a}}$ & $2.94 \pm 0.11^{\mathrm{a}}$ & $4.83 \pm 051$ & $3.33 \pm 0.40^{\mathrm{b}}$ & $2.77 \pm 0.13^{\mathrm{b}}$ \\
\hline 30 & $2.14 \pm 0.08^{\mathrm{a}}$ & $1.68 \pm 0.10^{\mathrm{a}}$ & $1.27 \pm 0.21^{\mathrm{a}}$ & $4.18 \pm 0.79^{\mathrm{b}}$ & $3.35 \pm 0.22^{\mathrm{b}}$ & $3.71 \pm 0.43^{\mathrm{b}}$ \\
\hline 45 & $2.28 \pm 0.13^{\mathrm{a}}$ & $1.41 \pm 0.04^{\mathrm{a}}$ & $2.68 \pm 0.25^{\mathrm{a}}$ & $4.74 \pm 0.71$ & $4.57 \pm 0.44^{\mathrm{b}}$ & $3.30 \pm 0.07^{\mathrm{b}}$ \\
\hline 60 & $2.40 \pm 0.24^{\mathrm{a}}$ & $1.27 \pm 0.05^{\mathrm{a}}$ & $1.89 \pm 0.19^{\mathrm{a}}$ & $3.40 \pm 0.88^{\mathrm{b}}$ & $2.28 \pm 0.35^{\mathrm{b}}$ & $4.13 \pm 0.81^{\mathrm{b}}$ \\
\hline 75 & $2.23 \pm 0.19^{\mathrm{a}}$ & $0.91 \pm 0.06$ & $1.29 \pm 0.24^{\mathrm{a}}$ & $2.00 \pm 0.31^{\mathrm{b}}$ & $2.26 \pm 0.19^{\mathrm{b}}$ & $1.28 \pm 0.48^{\mathrm{b}}$ \\
\hline 90 & $2.00 \pm 0.06^{\mathrm{a}}$ & $0.82 \pm 0.07$ & $0.73 \pm 0.10$ & $2.43 \pm 0.34^{\mathrm{b}}$ & $2.66 \pm 0.18^{\mathrm{b}}$ & $2.80 \pm 0.09^{\mathrm{b}}$ \\
\hline 105 & $1.92 \pm 0.15^{\mathrm{a}}$ & $1.50 \pm 0.23^{\mathrm{a}}$ & $0.41 \pm 0.01$ & $3.04 \pm 0.37^{\mathrm{b}}$ & $1.78 \pm 0.21^{\mathrm{b}}$ & $1.69 \pm 0.24^{\mathrm{b}}$ \\
\hline Control & \multicolumn{7}{|c|}{$0.64 \pm 0.07$} & \multicolumn{4}{|c|}{$5.67 \pm 1.25$} & \\
\hline
\end{tabular}

Podagrica uniforma

Data expressed as Mean \pm Standard deviation (values obtained in duplicates)

RCSKE-Ricinus communis seed kernel extract

CYPER-M- Cypermethrin

CPF- Chlorpyrifos

a- Statistically high compared to control

b- Statistically low compared to control

Table 2. Effects of RCSKE, Cypermethrin and Chlorpyrifos on superoxide dismutase (SOD) activity in

\begin{tabular}{|l|l|l|l|l|l|l|}
\hline \multirow{2}{*}{ Conc. $(\mu \mathrm{g} / \mathrm{ml})$} & \multicolumn{3}{|l|}{ SOD activity (U/mg protein) in Podagrica sjosdteti } & \multicolumn{3}{l|}{ SOD activity (U/mg protein) in Podagrica uniforma } \\
\cline { 2 - 7 } & RCSKE & Cypermethrin & Chlorpyrifos & CRSKE & Cypermethrin & Chlorpyrifos \\
\hline 15 & $9.21 \pm 2.20^{\mathrm{b}}$ & $8.64 \pm 1.54^{\mathrm{b}}$ & $11.70 \pm 2.18^{\mathrm{b}}$ & $5.50 \pm 0.98^{\mathrm{b}}$ & $7.50 \pm 1.55$ & $6.60 \pm 1.00$ \\
\hline 30 & $8.64 \pm 2.01^{\mathrm{b}}$ & $8.64 \pm 2.17^{\mathrm{b}}$ & $12.50 \pm 2.11^{\mathrm{b}}$ & $4.95 \pm 2.26^{\mathrm{b}}$ & $7.15 \pm 1.68$ & $6.60 \pm 0.96$ \\
\hline 45 & $7.85 \pm 2.10^{\mathrm{b}}$ & $10.90 \pm 3.22^{\mathrm{b}}$ & $12.23 \pm 2.59^{\mathrm{b}}$ & $5.05 \pm 0.93^{\mathrm{b}}$ & $5.56 \pm 1.05^{\mathrm{b}}$ & $8.25 \pm 1.89$ \\
\hline 60 & $8.64 \pm 1.10^{\mathrm{b}}$ & $10.20 \pm 2.04^{\mathrm{b}}$ & $8.14 \pm 1.78^{\mathrm{b}}$ & $4.50 \pm 0.81^{\mathrm{b}}$ & $6.05 \pm 1.01$ & $7.15 \pm 1.06$ \\
\hline 75 & $5.50 \pm 0.91^{\mathrm{b}}$ & $8.61 \pm 2.71^{\mathrm{b}}$ & $9.42 \pm 1.95^{\mathrm{b}}$ & $4.51 \pm 1.12^{\mathrm{b}}$ & $6.60 \pm 1.88$ & $8.80 \pm 1.06$ \\
\hline 90 & $9.40 \pm 2.17^{\mathrm{b}}$ & $12.60 \pm 1.76^{\mathrm{b}}$ & $13.30 \pm 4.59^{\mathrm{b}}$ & $4.12 \pm 0.44^{\mathrm{b}}$ & $2.20 \pm 0.91^{\mathrm{b}}$ & $7.70 \pm 2.05$ \\
\hline 105 & $4.71 \pm 0.78^{\mathrm{b}}$ & $14.10 \pm 3.29$ & $10.20 \pm 2.32^{\mathrm{b}}$ & $3.85 \pm 0.17^{\mathrm{b}}$ & $5.53 \pm 2.03^{\mathrm{b}}$ & $7.26 \pm 1.25$ \\
\hline Control & \multicolumn{7}{|c|}{$16.50 \pm 3.11$} & \multicolumn{2}{|c|}{$7.15 \pm 1.20$} & \\
\hline
\end{tabular}

Podagrica sjosdteti and Podagrica uniforma

Data expressed as Mean \pm Standard deviation (values obtained in duplicates)

RCSKE-Ricinus communis seed kernel extract

CYPER-M- Cypermethrin

CPF- Chlorpyrifos

a- Statistically high compared to control

b- Statistically low compared to control 


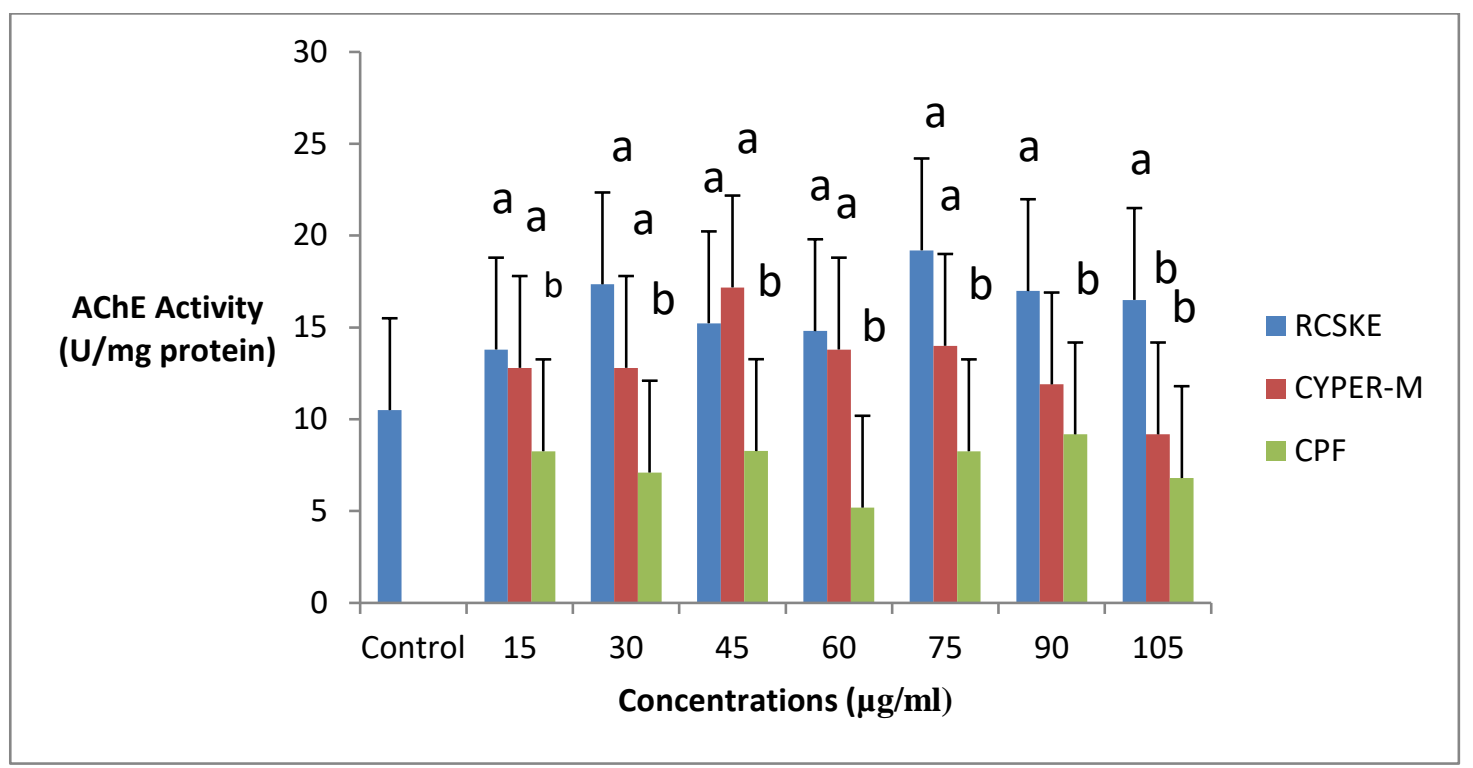

Fig 5. Effects of RCSKE, Cypermethrin and Chlorpyrifos on Acetylcholinesterase activity in Podagrica sjosdteti

Data expressed as Mean \pm Standard deviation (values obtained in duplicates)

RCSKE-Ricinus communis seed kernel extract

CYPER-M- Cypermethrin

CPF- Chlorpyrifos

a- Statistically high compared to control

b- Statistically low compared to control

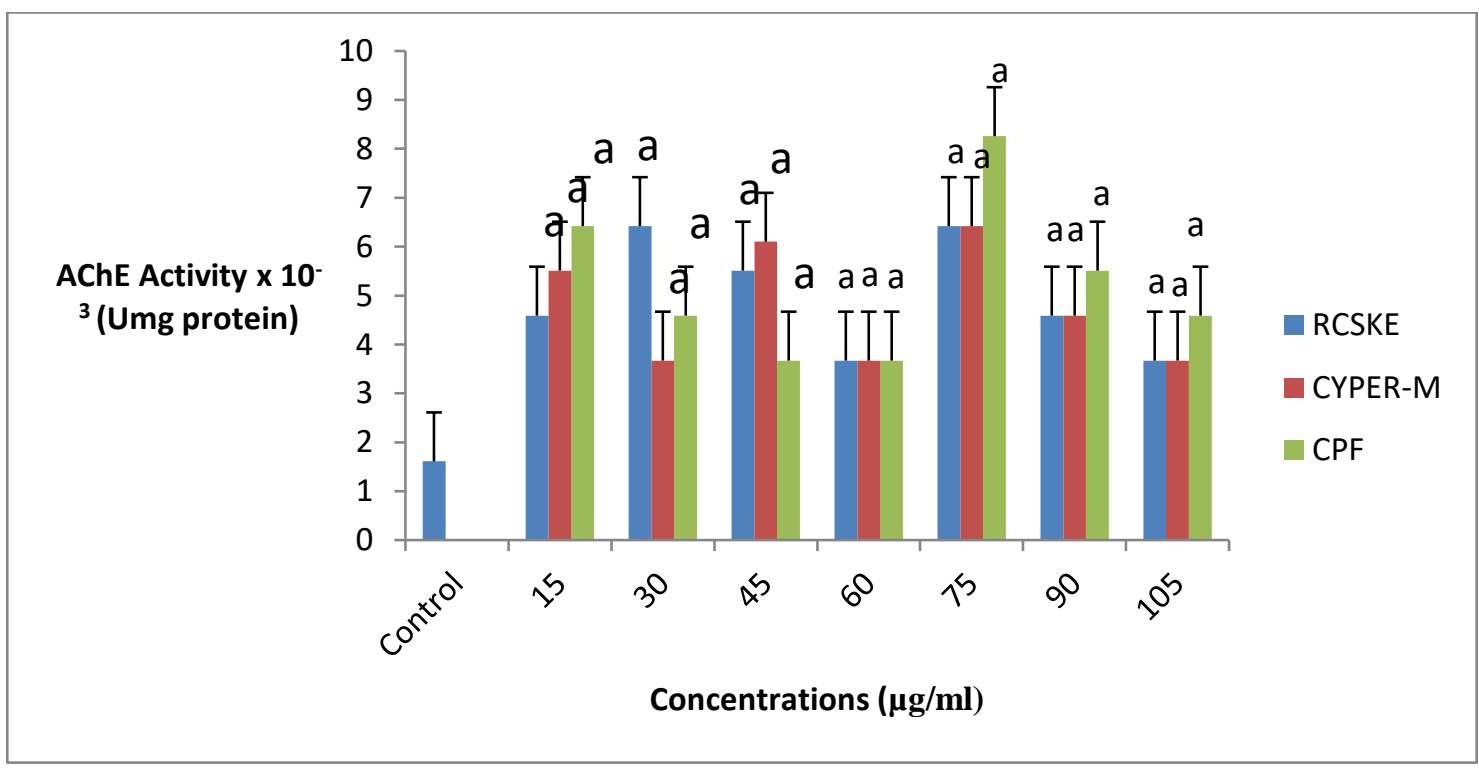

Fig. 6. Effects of RCSKE, Cypermethrin and Chlorpyrifos on Acetylcholinesterase activity in Podagrica uniforma

Data expressed as Mean \pm Standard deviation (values obtained in duplicates)

RCSKE-Ricinus communis seed kernel extract

CYPER-M- Cypermethrin

CPF- Chlorpyrifos

a- Statistically high compared to control 
b- Statistically low compared to control

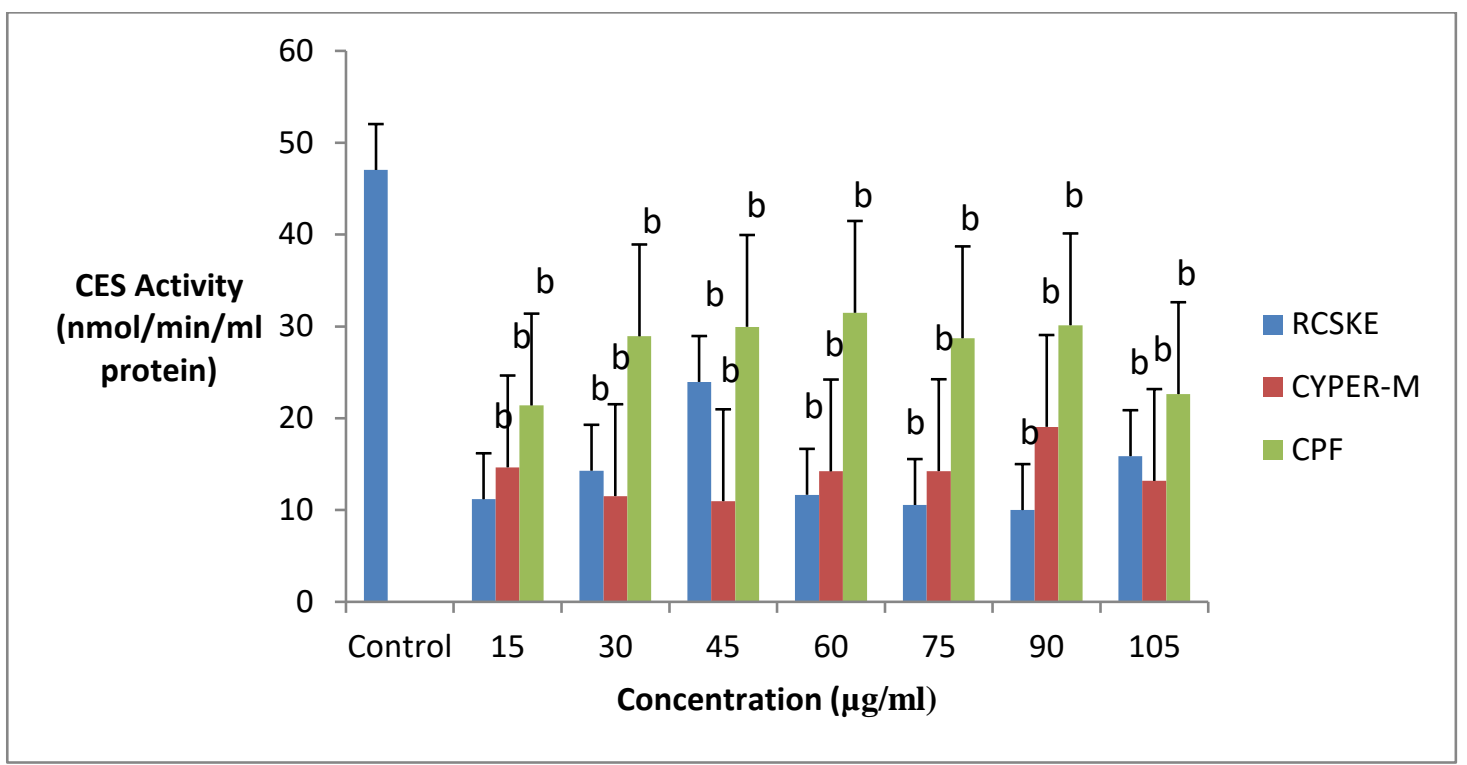

Fig 7. Effects of RCSKE, Cypermethrin and Chlorpyrifos on Carboxylesterase activity in Podagrica sjosdteti

Data expressed as Mean \pm Standard deviation (values obtained in duplicates)

RCSKE-Ricinus communis seed kernel extract

CYPER-M- Cypermethrin

CPF- Chlorpyrifos

a- Statistically high compared to control

b- Statistically low compared to control

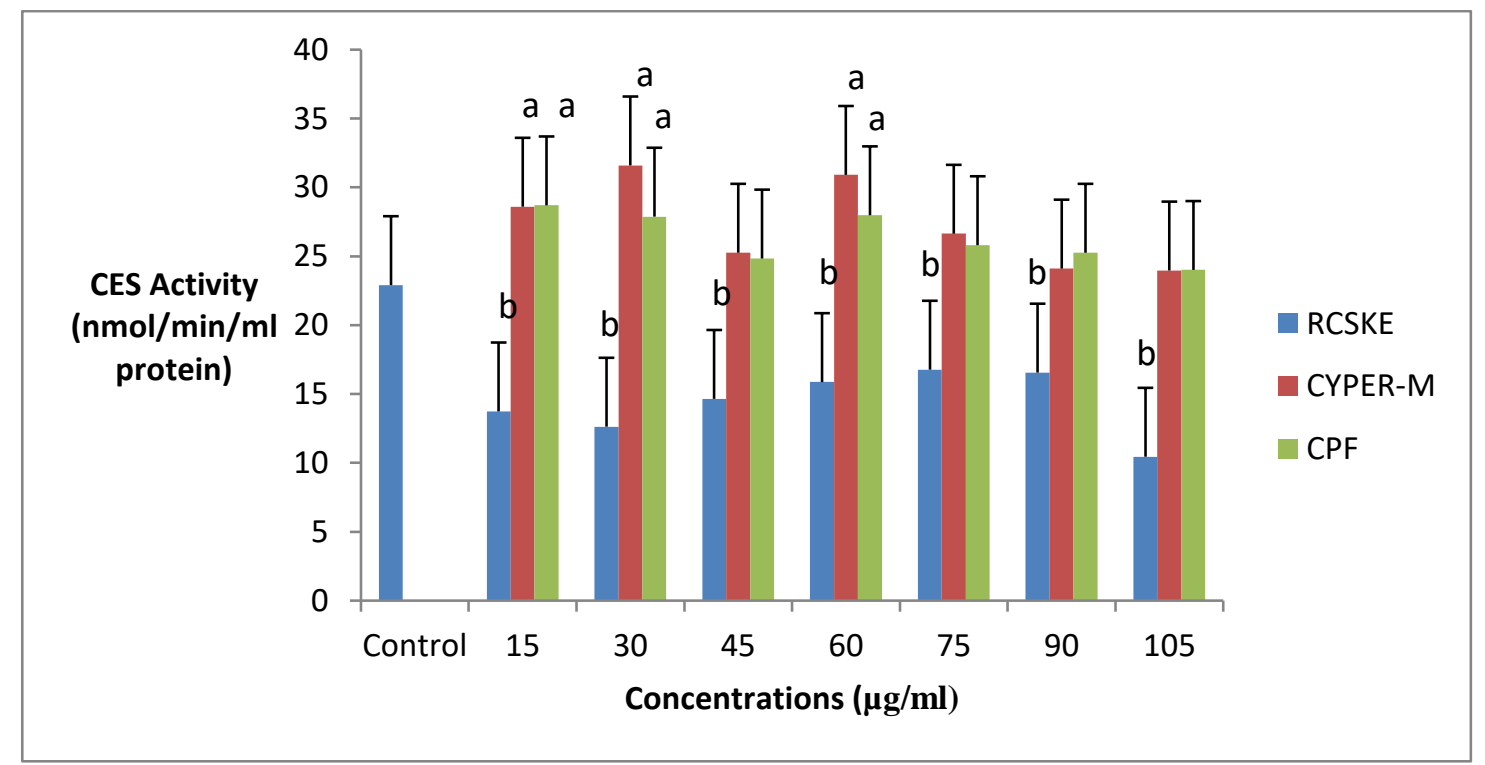

Fig 8. Effects of RCSKE, Cypermethrin and Chlorpyrifos on Carboxylesterase activity in Podagrica uniforma

Data expressed as Mean \pm Standard deviation (values obtained in duplicates)

RCSKE-Ricinus communis seed kernel extract

CYPER-M- Cypermethrin

CPF- Chlorpyrifos 
a- Statistically high compared to control

b- Statistically low compared to control

Table 3. Inhibitory concentration-50 ( $\left.\mathrm{IC}_{50}\right)$ values of RCSKE, Cypermethrin and Chlorpyrifos on Carboxylesterase activities in the two Podagrica species

\begin{tabular}{|l|c|c|}
\hline \multirow{2}{*}{ Treatments } & Podagrica sjosdteti & Podagrica uniforma \\
\cline { 2 - 3 } & $\mathrm{IC}_{50}$ values $(\mu \mathrm{g} / \mathrm{ml})$ & IC $_{50}$ values $(\mu \mathrm{g} / \mathrm{ml})$ \\
\hline RCSKE & 2.66 & 2.49 \\
\hline Cypermethrin & 2.37 & Indeterminate \\
\hline Chlorpyrifos & 2.65 & Indeterminate \\
\hline
\end{tabular}

RCSKE- Ricinus communis seed kernel extract

\section{Discussion}

Over the years, synthetic pesticides have been applied in combating the menace of several insect pests, both on field and in stores. These synthetic compounds have been noted with negative effects on humans and other untargeted subjects in the environment. Several studies have therefore established the importance of pesticides from botanical sources, in controlling several field, store and household insect pests, due to their potency, safety and ecological friendliness (Lenora and Senthikumar, 2017; Buxton et al., 2017; Acero, 2018).

We analyzed RCSKE using both IR and UV spectroscopy in order to detect possible functional groups of compounds present in the extract. The Infra red (IR) spectrum of $R$. communis seed kernel extract (RCSKE) shows ten notable peaks at $1082.8 \mathrm{~cm}^{-1}, 1161.1 \mathrm{~cm}^{-1}, 1239.3 \mathrm{~cm}^{-1}, 1459.7 \mathrm{~cm}^{-1}, 1541.3 \mathrm{~cm}^{-1}, 1654.9 \mathrm{~cm}^{-1}, 2855.1$ $\mathrm{cm}^{-1} 2926.0 \mathrm{~cm}^{-1}, 3013.6 \mathrm{~cm}^{-1}$ and $3289.4 \mathrm{~cm}^{-1}$. Comparing this result with the report of Fessenden and Fessenden (1986) and some others (Ayatollahi et al., 2011; Hossain and Ismail, 2013; Adeleke et al., 2018), the possible functional groups present in RCSKE include ether bond $\left(1082.8 \mathrm{~cm}^{-1}\right)$, ester bond $\left(1161.1 \mathrm{~cm}^{-1}\right.$ and $\left.1239.3 \mathrm{~cm}^{-1}\right)$, aromatic or aryl ring $\left(1459.7 \mathrm{~cm}^{-1}\right.$ and $\left.1541.3 \mathrm{~cm}^{-1}\right)$, asymmetric ethylenic double bond or carbonyl group (1654.9 $\left.\mathrm{cm}^{-1}\right)$, methyl stretching or aliphatic C-H bond $\left(2855.1 \mathrm{~cm}^{-1}\right)$, methyl bending $(2926.0$ $\left.\mathrm{cm}^{-1}\right)$, hydroxyl or amine stretching $\left(3013.6 \mathrm{~cm}^{-1}\right)$ and aliphatic hydroxyl or carboxylic acid group $\left(3289.4 \mathrm{~cm}^{-1}\right)$. The Ultra violet (UV) spectroscopy of the extract was found to depict absorptions at four different wavelengths at $222.5 \mathrm{~nm}, 228.5 \mathrm{~nm}, 258.5 \mathrm{~nm}$ and $275.5 \mathrm{~nm}$. Carbonyl group has been reported to absorb UV radiation maximally at around $211 \mathrm{~nm}$ (Bulus et al., 2011), while conjugated double absorbs at around 257nm (Hossian and Ismail, 2013). The GC chromatogram of RCSKE exhibits nine different peaks, including ethyl ester, diethyl phthalate, 1,4a-Lactone, Gibb- 3-ene-1, oleic acid, ricinoleic acid, ricinine, ricin and octadecanoate. On using their respective peak areas from the GC chromatogram to calculate the percentage compositions in the extract, we found out that ricinine $(30.31 \%)$ was the highest, followed by oleic acid $(27.33 \%)$ and ricin $(16.68 \%)$. It is worthwhile to suggest that the presence of ricinine in the extract may have been responsible for the ether, carbonyl and methyl groups (stretching and bending), while the aromatic ring may have been contributed by diethyl phthalate, as revealed from both the IR and GC results. Similarly, while the ester bond observed in IR spectrum of RCSKE in the present study is likely to be generated from ethyl ester, diethyl phthalate and octadecanoate, the ethylenic double bond may possibly be due to the presence of Gibb-3-ene-1, as revealed from the result of GC analysis. Furthermore, the carboxylic acid and amine groups shown from the IR analysis may have been generated from oleic and ricinoleic acids (fatty acids), and ricin (protein), respectively, as depicted in the GC chromatogram. Hussain et al. (2015) showed that a GC-MS analysis of methanol leaf extract of $R$. communis revealed the presence of n-hexadecanoic acid; octadecanoic acid; diethyl phthalate; ethyl ester; Gibb3-ene-1, 10-dicarboxylic acid; 1,4a lactone and 2,4a, 7-trihydroxy-1-methyl-8-methylene. The UV absorption by RCSKE at around $222.5 \mathrm{~nm}$ may indicate presence of carbonyl group (possibly generated from lactone and ricinine), while the absorption at around $258 \mathrm{~nm}$ may suggest double bond supplied by Gibb-3-ene-1, as shown from the GC result. However, from the HPLC profile of RCSKE, six prominent peaks were observed, whose retention times are $1.309 \mathrm{~min}, 1.476 \mathrm{~min}, 1.804 \mathrm{~min}, 2.593 \mathrm{~min}, 3.252 \mathrm{~min}$ and $5.446 \mathrm{~min}$. Certain studies have shown that the shoot part of castor plant is rich in substances like ricin, ricinine, $N$-demethylricinine and flavonoids (Kang et al., 1985). Although both ricin and ricinine have been noticed as potent antifeedant, insecticidal and repellent agents, ricinine has been reported to exhibit the highest level of insecticidal potential 
(Kang et al., 1985; Sharma and Sharma, 1998). The chromatographic and spectroscopic analyses in this study have thus shown the presence of some possible insecticidal agents in the extract of castor seed kernel.

Oxidative stress develops from the imbalance between the reactive oxygen species (ROS) and antioxidant defense system in an organism, resulting in oxidation of macromolecules, including nucleic acids, proteins and lipids, which culminates in several events, such as, altered gene expression (Allen and Tresini, 2000), uncontrolled cell proliferation (Toyokuni, 2006), genomic or chromosome instability and genetic mutation (Ishikawa et al., 2008; Kumar et al., 2008).. Insects have been described to possess a complex network of enzymatic antioxidant systems protecting them against the deleterious effects of ROS generated during exposures to insecticides and phytotoxins (Felton and Summer, 1995; Rajapakse and Walter, 2007). Superoxide dismutase (SOD) and Catalase are two important antioxidant enzymes, responsible for mopping of ROS in insects. While SOD converts superoxide anion into hydrogen peroxide, Catalase converts the hydrogen peroxide into water and molecular oxygen (Aucoin et al., 1991; Koslov and Weidinger, 2015). A few studies have shown elevated activities and expression of SOD genes in insects after exposure to insecticides. A recent microarray study revealed elevated transcription of SOD enzymes in pesticide-resistant strains of Anopheles arabiensis (Nardini et al., 2013) and Cimex lectularius (Mamidala et al., 2012), suggesting the roles of these enzymes in the detoxification of intracellular toxins, which eventually contributes to the pesticide resistance in these insects. Studies have shown that some insects in the diptera group exhibited Catalase activity against oxidative stressinduced aging, and improvement of survival and fecundity (Das et al., 2001; Hector et al., 2011). In addition, inactivation or silencing of this enzyme in Drosophila melanogaster (Mackay and Bewley, 1989), Musca domestica (Allen et al., 1983), Rhodnius prolixus (Paes et al., 2001) and Anopheles gambiae (Magalhaes et al., 2008) resulted in ROS-induced high mortality in these insects. In our present investigation, we found out that RCSKE, CYPER-M and CPF significantly increased the in vitro activity of Catalase in P. sjosdteti, whereas the activity was reduced in $P$. uniforma. The RCSKE, CYPER-M and CPF were observed to significantly reduce the activity of SOD in $P$. sjosdteti at all the concentrations, whereas the enzyme activity in $P$. uniforma was reduced on treatment with only RCSKE and CYPER-M, with CPF having no significant effect. It could thus be suggested from this result, that although the activity of Catalase enzyme was induced by the three agents in $P$. sjosdteti, the inhibition of SOD activity may compromise proper dismutation of superoxide radicals to hydrogen peroxide, leading to oxidative stress in the insect. On the other hands, both Catalase and SOD were inhibited in $P$. uniforma, which could potentially lead to accumulation of hydrogen peroxide and oxidative stress in the insect. The finding thus far, may suggest insecticidal effects of the castor extract, CYPER-M and CPF in both $P$. sjosdteti and P. uniforma, via suppression of the antioxidant enzymes.

Lastly, we investigated the activities of Acetylcholinesterase (AChE) and Carboxylesterase (CEs) in the two Podagrica species. AChE is an important enzyme, catalyzing the hydrolysis of acetylcholine to choline and acetate at the synaptic junctions (Dvir et al., 2010). In mammals, insecticides, like Organophosphates (e.g. Chlorpyrifos) and Carbamates, are irreversible inhibitors of AChE, causing continuous contraction of muscles, as acetylcholine floods the synapse (Cochran, 2011). The activity of AChE have been also identified in insects, such as Drosophila melanogaster (Fournier et al., 1989), Grasshopper (Weill et al., 2002) and mosquitoes (Kim et al., 2013), to mention a few. In the present study, RCSKE and Cypermethrin caused significant elevation in AChE activity in both $P$. sjosdteti and $P$. uniforma, which may result in a low level of ACh available for neuronal actions and subsequent adverse effect on muscular excitation. Similarly, the observed decrease in AChE activity by Chlorpyrifos in P. uniforma could cause a delayed ACh hydrolysis and its accumulation at the synapse, resulting also in uncontrolled muscular excitation in the insect. This finding therefore may suggest possible implications of RCSKE, Cypermethrin and Chlorpyrifos in causing toxicity in the neuronal system of the two flea beetles been investigated. CE enzymes on the other hands have been associated with the ability to confer substantial protection and resistance on insects through hydrolysis of Organophosphate insecticides, according to the report of Jackson et al. (2010). However, the present study has revealed that the castor extract (RCSKE), CYPER-M and Chlorpyrifos significantly inhibited the in vitro activity of CE in P. sjosdteti. This finding is quite consistent with the Probit analysis, which has shown that the $\operatorname{IC}_{50}$ value of RCSKE $(2.66 \mu \mathrm{g} / \mathrm{ml})$ was comparable to those of Cypermethrin $\left(\mathrm{IC}_{50}=2.37 \mu \mathrm{g} / \mathrm{ml}\right)$ and Chlorpyrifos $\left(\mathrm{IC}_{50}=2.65 \mu \mathrm{g} / \mathrm{ml}\right)$ in their inhibition against CE enzyme in P. sjosdteti. However, while CYPER-M and Chlorpyrifos increased CE activities in $P$. uniforma, (hence their $\mathrm{IC}_{50}$ values were indeterminable), RCSKE substantially reduced the activity $\left(\mathrm{IC}_{50}=2.49 \mu \mathrm{g} / \mathrm{ml}\right)$ at all the concentrations used in the study. We can therefore conclude that the extract of Ricinus communis (Castor) seed kernel contains certain bioactive agents that could potentially inhibit the antioxidant and hydrolytic enzymes in $P$. sjosdteti and $P$. uniforma, flea beetles, in a manner comparable to the commercial pesticides, Cypermethrin and Chlorpyrifos.

\section{REFERENCES}

Sabina E.P., Rasool M.K., Mathew L. et al.. (2009). Studies on the protective effect of Ricinus communis leaves extract on carbon tetrachloride hepatotoxicity in albino rats. Pharmacologyonline. 2: 905-916. 
Salihu B.Z., Gana A.K., Amosun A., Shaahu A.., Agboire S.A., Apuyor B.O., Oliseh A. (2013). Morphological Characterization of Castor (Ricinus communis L.) Accessions. Proc. Agricultural Society of Nigeria.. 308-316.

Aziz S., Rabnibwaz A., Rehman H. and Ghani K.S. (2016). Phytochemical and Biological Screening of Ricinus communis seed oil grown wild in Jammu and Kashmiri. Journal of Phamacognosy and Phytochemistry. 5 (3): 89-92.

Aplin P.J. and Eliseo T. (1997). Ingestion of castor oil plant seeds. The Medicinal Journal of Australia. 167: 260261.

Gana A.K., Yusuf A.F. and Apuyor B. (2013). Castor Oil Plant and its Potential in Transformation and Industrialization of Under Developing Nations in the World. Advanced Journal of Agricultural Research. 1(005): 072-079.

NCRI, (2014). "Castor Breeding, National Cereal Research Institute, Nigeria”. Report of castor germplasm collections and stakeholder identification.

Ogunniyi D.S. (2006). Castor Oil: A vital industrial raw material. Bioresour. Technol. 97(9): 1086-1091.

Worbs S., Kohler K., Pauly D., Avonder M.A., Schaer M., Dorner M.B. et al. (2011). Ricinus communis intoxications in human and Veterinary Medicine. A summary of Real Cases Toxins (Basel). 3 (10): 1332-1372.

Coopmann V., De Leeuw M., Cordonnier J., Jacobs W. (2009). Succidal death after injection of castor extract (Ricinus communis L.). Forensic Sci. Int. 189 1-3): e13-20.

Balali-Mood M. and Moshiri M. (2015). Problems of Clinical diagnosis and management of a adeliberate Biological Born Disease. J. Bioterror Bodef. 6e : 113.

Trease G.E., Evans W.C. (1989). Pharmacognosy 2nd Edition, Bailliere Tindall, Eastbourne, 74-78.

Edeoga H.O., Okwu D.E., Mbaebie B.O. (2005). Phytochemical constituents of some Nigerian medicinal plants. Af.r J Biotechnol. 4: 685-688.

Audi J., Belson M., Patel M., Sceir J., Osterloh J. (2005). Ricin poisoning: A comprehensive review. JAMA the Journal of the American Medical Association. 294 (18): 2342-2351.

Berman P., Nisri S., Wiesman Z. (2011). Castor oil biodiesel and its blends as alternative fuel. Biomass Bioenergy. 35: $2861-2866$.

ICOA. (2013). The processing of castor meal for detoxification and deallergenation. International Castor Oil Assoc., Cinnaminson, NJ.

Salihu B.Z., Gana A.K., Amosun A., Shaahu A., Agboire S.A., Apuyor, B.O., Oliseh, A. (2013). Morphological Characterization of Castor (Ricinus communis L.) Accessions. Proc. Agricultural Society of Nigeria. Pp. 308-316.

Upasani S.M., Kotkar H.M., Mendki P.S., MaheshwariV.L. (2003). Partial characterization and insecticidal properties of Ricinus communis L. foliage flavonoids. Pest Manag Sci., 59 (12): 1349-1354.

Tinzaara W., Tushemereirwe W., Nankinga C.K., Gold C.S., Kashaija I. (2006). The potential of using botanical insecticides for the control of the banana weevil, Cosmopolites sordidus (Coleoptera: Curculionidae). Afr. J. Biotechnol., 5 (20): 1994-1998.

Rossi G.D., Santos C.D., Carvalho G.A., Alives D.S., Pereira L.L.S., Carvalho G.A. (2012). Biochemical analysis of castor bean leaf extract and its insecticaidal effect against Spodoptera frugiperda (Smith) (Lepidoptera: Noctuidae). Neotrop. Entomol. 41: 503-509.

Singh A., Kaur J. (2016). Toxicity of leaf extracts of Ricinus communis L. (Euphorbiaceace) against the third instar larvae of Musca domestica L. (Diptera: Muscidae). American Journal of Bioscience. 4(3-1): 5-10.

Lamb R.J. (1984). Effects of flea beetles, Phyllotreta spp. (Coleoptera: Chrysomellidae) on the survival, growth, seedyeild of Canola, rape and yellow mustard. Can. Entomol. 116: 269-280.

Neuwinger H.D. (1996). African ethnobotany: Poisons and drugs: chemistry, pharmacology, toxicology. Chapman \& Hall, London, $941 \mathrm{pp}$.

Jerez V. (1999). Biology and ecology of Procalus Clark, 1865, endemic to the Andino-Patagonian region (Alticinae). In: Cox ML. (Ed) Advances in Chrysomelidae Biology 1. Backhuys Publishers, Leiden: 545-555.

Furth D.G., Lee J.E. (2000). Similarity of the Blepharida-group genera using larval and adult characters (Coleoptera: Chrysomelidae: Alticinae). Journal of the New York Entomological Society 108: 26-51.

Zhang L.J., Yang X.K. (2008). Description of the immature stages of Ophrida xanthospilota (Baly) (Coleoptera: Chrysomelidae) from China. Proceedings of the Entomological Society of Washington 11: 693-700.

Chaboo C.S. (2011). Defensive behaviors in leaf beetles: From the unusual to the weird. In: Vivanco J, Weir T. (Eds) Chemical Biology of the Tropics. Springer Verlag, Berlin: 59-69. 
Ojo J.A., Odunayo A.A., Ibitayo O. (2014). Evaluation of botanical insecticides against flea beetles, Podagrica sjosdteti and Podagrica uniforma, of okra. Int. Journal of Advanced Research. 2(4): 336-244.

Odebiyi J.A. (1980). Relative abundance and seasonal occurrence of Podagrica spp. (Coleoptera: Chrysomelidae) on okra in south Western Nigeria. Afr. J. Agric. Sci. 6: 83-84.

Osisanya E.O., Tayo T.O. (1981). Assessment of damage caused by the leaf eating beetle, Podagrica spp. on okra in southern Western Nigeria. Afr. J. Agric. Sci. 1: 123-141.

Abebe E.A. (2015). Cotton flea beetle, Podagrica ponticolis weise Coeoptera: Halticdae) in Metema District , Northern Ethiopia: Yield loss assessment and management. Open Access Library Journal. 2(01): 1-10.

Fasunwon B.T., Banjo A.D. (2010). Seasonal population fluctuations of Podagrica species on okra plant (Abelmoschus esculentus (L.) Moench.). Research Journal of Agriculture and Biological Sciences, 6 (3): 283-288.

Fajinmi A.A., Fajinmi O.B. (2010). Incidence of okra mosaic virus at different growth stages of okra plants (Abelmoschus esculentus (L.) Moench) under tropical condition. Journal of General Molecular Virology. 2: 28-31.

Walker G.R., Negis S.S. (1958). Isolation of Ricin, Ricinine and the allergenic fraction from castor seed pomace from two different sources. Journal of the American oil Chemists Society. 35(8): 409-412.

Lowry O.H., Rosbrough N.J., Farr A.L., et al. (1951). Protein measurement with the Folin-phenol reagent. J. Biol. Chem. 193: 265-275.

Misra H.P., Fridovch J. (1975). The role of superoxide anion in the autoxidation of epinephrine and a simple assay for superoxide dismutase. J. Biol. Chem 247: 3170-3175.

Aebi H. (1984). Catalase in vitro. In: Packer L. Editor. Methods in Enzymology. Orlando FL: Academic Press. pp 121-126.

Ellman G.L., Courtney K.D., Andres V. Jr., Featherstone Y. (1961). A new and rapid colorimetric determination of acetylcholinesterase activity. Biohem. Pharmacol. 7: 88-95.

Nachmanshon D., Neumann E. (1975). In: Chemical and Molecular Basis of Nerve activity, Academic Press, New York.

Clement J.G., Erhardt N. (1990). Serum Carboxylesterase activity in various strains of rats: sensitivity to inhibition by CBDP (2-O-cresyl 4H:1::3:2-benzodioxaphosphorin-2-oxide). Arch. Toxicol. 64: 414416.

Annie S.W., Raveen R., Paulraj M.G., Samuel T., Arivoli S. (2015). Screening of Eichhornia crassipse (Mart) solms (Pontederiaceae) crude laef extracts for larvacidal efficacy against the filarial vector Culex quinquefasciatus Say (Diptera: Cukicidae). Int. Journal of Mosquito Res. 2(4): 43-48.

Lenora L.M., Senthikumar N. (2017). Insecticidal potential of Aquatic Alien weed, Eichhornia crasspes (Mart) Solms on Tobacco Caterpillar, Spodoptera litura (F). Asian Journal of Plant Science and Research. 7(1): 1-6.

Buxton T., Takahashi S., Niwata I., Owusu E.O., Kim C-S. (2017). Isolation and characterization of the insecticidal compounds in Anacardium occidentale (Cashew nut) liquid against the rice weevil, Sitophilus oryzae L. (Coleoptera: Curculionidae). Journal of Entomology and Zoology studies. 5(2): 1241-1246.

Acero L.H. (2018). Cashew (Anacardium occidentale) nut shell ethanol extreact in the control of Cockroach (Periplaneta Americana). Sci. Int.(Lahore). 30(3): 427-429.

Fessenden R.J., Fessenden J.S. (1986). Organic Chemistry (3 edition).Brooks/ Cole Publishing Company, Monterey, California.

Ayatollahi A.M., Mustafa G., Suleiman A., Omer M.A., Mehdi M., et al. (2011). Pentacyclic triterpenes in Euphorbia microsciadia with their T-cell proliferation activity. Iranian J Pharma Res. 10 (2): 287-294.

Hossain M.A., Ismail Z. (2013). Isolation and characterization of triterpenes from the leaves of Orthosiphon stamineus. Arab J. Chem. 6: 295-298.

Adeleke G.E., Arinde O.O., J.O. Fatoki., Adedosu O.T. (2018). Identification of Betulinic acid in ethanol extract of Vitellaria paradoxa using spectroscopy and High-performance Liquid Chromatography. Journal of Pharmcognosy and Phytochemistry. 7(5): 571-576.

Bulus A., Abdu K.H., Mohanned I., Umar U.P., Tarfa D.F, Chido A.B., Gamaniel K.S. (2011). Structural characterization of ZS - 2A: An antiplasmodial compound isolated from Zizyphus spina-christi Root Bark. J. pharm and Nut Sci. 1: 48-53.

Hussain A.O., Hamed I.M., Jasim H., Kareem M.A. (2015). Determination of alkaloid compounds of Ricinus communis by using Gas chromatography-Mass spectrometry (GC-MS). J. Med Plants Res. 9)10): 349359. 
Kang S., Cordell G., Soejarto D., Fong H. (1985). Alkaloids and flavonoids from Ricinus communis. J. Nat.Prod. 48(1): 155-156.

Sharma P.K., Sharma J.D. (1998). Plants showing antiplasmodial activity from crude extracts to isolated compounds. Indian J. Malariol. 35: 57-110.

Allen R.G., Tresini M. (2000). Oxidative stress and gene regulation. Free Radic. Biol. Med. 28, 463-499.

Toyokuni S. (2006). Novel aspects of oxidative stress-associated carcinogenesis. Antioxid. Redox. Signal. 8, 1373-1377.

Ishikawa K., Takenaga K., Akimoto M., Koshikawa N., Yamaguchi A., Imanishi H., Nakada K., Honma Y., Hayashi J. (2008). ROS-generating mitochondrial DNA mutations can regulate tumor cell metastasis. Sci. 320: 661-664.

Kumar B., Koul S., Khandrika L., Meacham R.B., Koul H.K. (2008). Oxidative stress is inherent in prostate cancer cells and is required for aggressive phenotype. Cancer Res. 68: 1777-1785.

Felton G.W., Summers C.B. (1995). Antioxidant systems in insects. Arch Insect Biochem Physiol. 29: 187-197.

Rajapakse C.N.K., Walter G.H. (2007). Polyphagy and primary host plants: oviposition preference versus larval performance in the lepidopteran pest Helicoverpa armigera. Arthropod Plant Interact. 1: 17-26.

Aucoin R.R., Philogene B.J.R., Arnason J.T. (1991). Antioxidant enzymes as biochemical defenses against phototoxin-induced oxidative stress in three species of herbivorous Lepidoptera. Arch Insect Biochem Physiol. 16: 139-152.

Koslov A.V., Weidinger A. (2015). Biological activities of Reactive Oxygen and Nitrogen Species: Oxidative Stress versus signal Transduction: Biomolecules 5 472-484.

Nardini L., Christian R.N., Coetzer N., Koekemoer L.L. (2013). DDT and pyrethroid resistance in Anopheles arabiensis from South Africa. Parasit Vectors. 6: 229.

Mamidala P, Wijeratne AJ, Wijeratne S, et al. (2012). RNA-Seq and molecular docking reveal multi-level pesticide resistance in the bed bug. BMC Genomics. 13: 6.

Das N., Levine R., Orr W., Sohal R. (2001). Selectivity of protein oxidative damage during aging in Drosophila melanogaster. Biochemical Journal 360: 209.

Hector D., Roanna M., Fernando A., Mauricio R.V., Rod J. et al. (2011). Reactive Oxygen Species Scavenging by Catalase IsImportant for Female Lutzomyia longipalpis Fecundity and Mortality Vector Group, Liverpool School of Tropical Medicine, Liverpool, United Kingdom, pp. 21-25.

Mackay W., Bewley G. (1989). The genetics of catalase in Drosophila melanogaster: isolation and characterization of acatalasemic mutants. Genetics.122: 643.

Allen R., Farmer K., Sohal R. (1983). Effect of catalase inactivation on levels of inorganic peroxides, superoxide dismutase, glutathione, oxygen consumption and life span in adult houseflies (Musca domestica). Biochemical Journal. 216: 503.

Paes M., Oliveira M., Oliveira P. (2001) Hydrogen peroxide detoxification in the mid-gut of the blood-sucking insect, Rhodnius prolixus. Archives of Insect Biochemistry and Physiology. 48: 63-71

Magalhaes D.E.B., Beier J.C., Foy B.D. (2008). Silencing an Anopheles gambiae catalase and sulfhydryl oxidase increases mosquito mortality after a blood meal. Archives of Insect Biochemistry and Physiology. 68: 134-143.

Dvir H., Silman I., Harel M., Rosenberry T. L., Sussman J. L. (2010). Acetylcholinesterase: from 3D structure to function. Chemicobiological interactions. 187: 10-22.

Cochran R. (2011). Oxime-assisted Acetylcholinesterase catalytic scavengers of Organophosphates that Resist Aging. The Journal of Biological Chemistry. 286(34): 29718-29724.

Fournier D. et al. (1989). Drosophila melanogaster acetylcholinesterase gene. Structure, evolution and mutations. Journal of Molecular Biology. 210:15-22.

Weill, et al. (2002). A novel acetylcholinesterase gene in mosquitoes codes for the insecticide target and is nonhomologous to the ace gene in Drosophila. Proceedings. Biological sciences / The Royal Society. 269: 2122.

Kim Y.H., Lee S.H., (2013). Which acetylcholinesterase functions as the main catalytic enzyme in the Class Insecta? Insect Biochemistry and Molecular Biology. 43: 47-53.

Jackson C.J., Oakeshott J.G., Sanchez-Hernandez J., Wheelock C. (2010). Carboxylesterases in the metabolism and toxicity of pesticides. In: Satoh T, Gupta RC, editors. Acetylcholinesterase Pesticides: Metabolism, Neurotoxicity and Epidemiology. New York: Wiley; pp. 57-77. 